\title{
Kelompok Pita Maha: Gerak Menuju Seni Lukis Modern Bali
}

Zuliati

Program Studi Seni Murni, FSRD, Institut Seni Indonesia Surakarta

Jln. Ring Road Mojosongo, Surakarta

Tlp.081804209909, E-mail: zuliatilantip@gmail.com

Volume 3 Nomor 1,

April 2016: 44-53

\begin{abstract}
ABSTRAK
Penelitian ini bertujuan untuk melihat dan memahami perubahan yang terjadi dalam seni lukis Bali sejak adanya Kelompok Pita Maha. Konsep mengenai seni lukis modern di Indonesia mempunyai perbedaan sejarah, baik dalam bentuk maupun isi, dengan wacana seni lukis modern di Barat yang monolinier-universalis-rasionalis. Wacana seni lukis modern yang menggejala di Indonesia (termasuk Bali) hadir melalui intervensi asing (penjajahan). Wacana seni lukis modern secara bersamaan telah meminggirkan seni-seni lain yang tidak memenuhi kriteria-kriteria "modern". Seni di luar kriteria modern kemudian disebut sebagai seni tradisi yang mempersempit dan mengecilkan keberadaannya. Sejarah perkembangan seni lukis di Bali menarik untuk dikaji karena terdapat pola yang khas karena warisan-warisan seni pada masa lalu masih terus hadir dalam seni lumkis masa kini. Tulisan ini tidak akan mempertentangkan antara seni lukis tradisi dengan seni lukis modern. Tulisan ini membahas pengaruh Kelompok Pita Maha terhadap modernisasi dalam seni lukis Bali. Data dikaji secara secara deskriptif-analitis dengan pendekatan sosio-historis mengenai perubahan-perubahan yang terjadi dalam seni lukis Bali dari tatanan seni lukis prakolonial menjadi tatanan seni lukis Bali masa kini.
\end{abstract}

Kata kunci: Pita Maha, seni lukis tradisional, seni lukis modern, Bali

\begin{abstract}
Pita Maha Group: The Motion Towards the Balinese Modern Paintings. The concept of modern painting in Indonesia has different histories, both in the form and content, with the discourse of modern painting in the West which is monolinier-universal-rationale. The discourse of modern painting implicated in Indonesia (including Bali) presents through colonization. Modern art at the same time has marginalized other arts that do not fullfill modern criteria. Art, outside the criteria of modern art is called as an traditional art that narrowed and lowered its existence. It is interesting to make a research about the development of painting history in Bali because there is a unique pattern showing the artistic legacy of the past which still presents in nowadays art. This paper will not focus on polarizing between traditional and modern painting. It is interesting to discuss it more descriptive-analytically with the social-historis approach on how the changes happened in Balinese painting of pre-colonial art to modern Balinese paintings of which the other one is the presence of the Pita Maha.
\end{abstract}

Keywords: Pita Maha, traditional painting, modern painting, Bali

\section{Pendahuluan}

Sejarah perkembangan seni rupa di Indonesia tidak selalu berjalan berkesinambungan. Dalam beberapa buku dijelaskan bahwa terjadi rupture atau keterputusan sejarah seni rupa di Indonesia. Salah satu yang memengaruhi sejarah perkembangan seni rupa di Indonesia adalah proses penjajahan bangsa asing terutama Belanda. Penjajahan oleh Belanda di Indonesia tidak saja memengaruhi aspek 
politik dan ekonomi, tetapi juga memperlihatkan pengaruh pada bidang kebudayaan termasuk kesenian. Menurut pandangan tersebut, seni rupa di Indonesia hari ini akan terdiri dari seni rupa modern di satu sisi dan seni tradisi di sisi yang lain.

Pandangan lain datang dari Claire Holt dalam bukunya yang berjudul Art in Indonesia: Continous and Change yang membuat pembabakan seni rupa Indonesia menjadi tiga, yaitu warisan-warisan masa lalu, tradisi-tradisi yang hidup, dan penemuanpenemuan baru. Menurut Claire Holt (2000), dalam sejarah perkembangan seni rupa di Indonesia terdapat kesinambungan sekaligus juga perubahanperubahan. Perkembangan seni lukis di Bali sendiri menunjukkan adanya kesinambungan yang terlihat pada warisan seni lukis yang mempunyai sifat dekoratif dan unsur-unsur tradisi pada penggunaan warna, komposisi, dan tema lukisan. Seni lukis di Bali menunjukkan pola yang khas karena jejakjejak seni rupa masa lalu masih bisa dilihat pada bentuk-bentuk kesenian yang masih hidup di Bali saat ini.

Pada awalnya, kebudayaan Bali terbentuk sebagai hasil perpaduan dari budaya Hindu di Jawa yang mengalami masa surut dan berpindah ke daerah Bali. Kebudayaan Hindu Jawa ini bertemu dengan kebudayaan Hindu yang sudah ada di Bali yang berasal dari India. Seni rupa Bali adalah warisan dari tatanan ideoreligius budaya agraris HinduBudha yang berkembang di Bali sekitar abad ke-10 ketika didirikan kerajaan-kerajaan yang mendapat pengaruh langsung dari kebudayaan India yang dibawa oleh para pendeta penyebar agama serta biarawan dan juga yang tercampur lewat kontakkontak dengan kerajaan Hindu dari Jawa khususnya pengaruh kerajaan Majapahit yang melakukan invasi pada tahun 1343 serta kontak-kontak dengan Cina dan beberapa daerah di Asia Tenggara (Holt 2000). Membicarakan peradaban Hindu di Indonesia pasti akan mengaitkan transformasi seni budayanya yang tetap bertahan dengan baik di Bali, selain itu seni rupa Indonesia-Hindu bukan semata-mata produk dari pendalaman pikiran atau persepsi dari teori dan kaidah seni atau ikonografi dari tradisi seni India (Sucitra 2015).

Teks lukisan tertua adalah sebuah torehan pada lempeng tembaga bersubjek gambar wayang yang menggambarkan sosok Dewa Siwa, ditemukan di Pura Kehen, Bangli, berangka tahun 1126 Saka (1204 M). Pada masa kekuasaan Kerajaan Gel Gel abad ke-15 telah ditemukan manuskrip-manuskrip lontar yang berisikan cerita-cerita pewayangan. Seni lukis Bali pada awalnya juga bisa dilacak pada ider-ider, yaitu lukisan strip yang biasanya digantungkan pada saat upacara agama, dipasang di bawah atap di seluruh bangunan rumah atau pura. Langse, yaitu hiasan dinding dengan tema palelintangan (kalender Bali) atau tema lainnya, dengan mengambil bentuk-bentuk pewayangan. Para pelukis di daerah Ubud dan sekitarnya banyak melukis bentuk-bentuk wayang dengan tema yang bersumber dari cerita Panji, Mahabharata, Ramayana seperti halnya sekarang masih dapat ditemui di Desa Kamasan. Para pelukis membuat lukisan dalam rangka kegiatan keagamaan dan kemasyarakatan.

Invasi Belanda pada tahun 1845-1848 di Bali utara dan 1906-1908 di Bali selatan berdampak cukup besar terhadap arah perkembangan seni lukis di Bali. Terjadinya perubahan dalam sistem pemerintahan dari pemerintahan tradisional kerajaan ke sistem kolonial yang mengakibatkan melemahnya salah satu pilar tradisional budaya Bali. Pengaruh istana atau puri semakin terbatas. Tatanan ekonomi dirombak total. Bali yang tadinya terpecah-pecah tidak hanya menjadi kesatuan pasar yang tunggal, tetapi disatukan dengan ruang ekonomi Hindia-Belanda. Kehadiran Belanda yang diikuti proses kolonisasi membawa dampak signifikan terhadap konsekuensi kultural seni yang awalnya berkembang atau bernaung para puri kemudian bergeser dan tumbuh di desa-desa. Karakteristik seni istana atau puri yang sangat ketat terhadap peraturan dan harus mengikuti pakempakem yang telah digariskan, mengalami beberapa penyesuaian untuk tumbuh di pedesaan (Vickers 2000).

Kehidupan kesenian masyarakat Bali mengalami perubahan dengan masuknya pendatang-pendatang asing, seiring dengan kebijakan pemerintah kolonial Belanda yang sengaja membuka pintu untuk kunjungan wisatawan ke Bali. Sejak kedatangan Walter Spies dan Rudolf Bonnet pada awal tahun 1930-an terjadi 
perubahan, tidak saja pada teknik-teknik melukis, tetapi juga pada konsep berkesenian itu sendiri. Sebelumnya di Bali tidak mengenal istilah seniman, orang yang membuat karya seni disebut ngayah (mengabdi untuk kepentingan puri). Kesenian Bali yang pada awalnya berada di lingkungan puri dan ditujukan untuk kepentingan keagamaan tersebut kemudian bergeser untuk kepentingan ekonomi sebagai komoditas perdagangan sejak hadirnya pendatang terutama orang-orang dari Belanda. Setelah memperkokoh kekuasaannya di Pulau Jawa, Belanda mulai melakukan ekspansi ke pulaupulau lain termasuk Bali. Kerajaan pertama yang diserang adalah Buleleng setelah rajanya menolak untuk takluk di bawah kekuasaan Belanda. Kemenangan Belanda atas Buleleng pada tahun 1845 kemudian disusul dengan penaklukan daerah lainnya. Puputan Badung dan Klungkung menjadi tanda berakhirnya kekuasaan tradisional kerajaankerajaan di Bali yang kemudian terintegrasi dalam pemerintahan Belanda (Couteau 1999).

Pemerintahan Belanda mendorong munculnya berbagai pembaruan dalam tradisi kesenian di Bali. Perubahan ini terjadi bersamaan dengan derasnya kunjungan wisatawan ke Bali, seiring kebijakan pemerintah kolonial Belanda yang sengaja membuka pintu untuk kunjungan wisatawan ke Bali. Kebijakan Belanda tersebut juga dipengaruhi oleh kondisi politik di negara asalnya yang pada tahun 1816 mengalami liberalisasi ekonomi dan mendorong terjadinya perubahan sosial di berbagai negara jajahannya, termasuk Hindia Belanda atau Indonesia. Swastanisasi di berbagai bidang tersebut menyebabkan banyak orang asing yang bekerja di perkebunan dan perusahaan-perusahaan swasta di Hindia Belanda. Golongan baru yang mempunyai kekuatan ekonomi muncul. Golongan baru tersebut turut serta mengembangkan gaya hidup kelas menengah baru yang di antaranya dengan berwisata ke Bali dan menikmati karya-karya seni termasuk seni lukis (Couteau 1999).

Muncul pasar baru yang membutuhkan ketersediaan karya-karya seni rupa untuk suvenir bagi para wisatawan asing yang datang ke Bali. Hal ini memengaruhi produksi karya seni rupa yang bertambah banyak. Percepatan produksi tersebut menyebabkan perubahan tema-tema lukisan dan menghilangnya simbol-simbol agama. Seniman mulai membuat lukisan dengan tema-tema yang diambil dari kehidupan sehari-hari seperti sabung ayam, upacara di pura, dan upacara pembakaran mayat yang tidak mempunyai kaitan langsung dengan fungsi ritual. Tema karya baru tersebut sebagian masih berangkat dari unsur-unsur tertentu kesenian lama, seperti relief cerita binatang Tantri atau Atmaprangsa (siksaan neraka). Selain itu, karena bahan dan alat baru mulai beredar, dinamika stilistik dipercepat (Couteau 1999).

Akhir dasawarsa 1920-an dan dasawarsa 1930-an ditengarai terjadi suatu fenomena unik, yaitu intervensi langsung dari seniman Barat, yang akan memberikan corak tersendiri dalam perkembangan seni pedesaan di Bali selanjutnya. Perkembangan itu ditandai dengan gerakan Pita Maha. Intervensi pihak asing dalam seni rupa di Bali dipengaruhi oleh mitos Bali sebagai "surga" tropis. Hal ini merupakan kelanjutan dari tren yang dimulai Gauguin pada akhir abad ke-19. Ketika Gauguin meninggalkan Perancis untuk bermukim dan berkarya di Tahiti, ia merintis pemindahan impian eskatologis Barat ke daerah-daerah yang baru ditaklukkan, termasuk Bali. Oleh karena itu berbondong-bondonglah aneka "penakluk juru mimpi” ke Bali dengan berbagai alasan baik sebagai petualang, hartawan, cendekiawan, ataupun seniman. Di antaranya terdapat figur Walter Spies (1895-1942) dan Rudolf Bonnet (1895-1978) yang keduanya akan memainkan peran yang menentukan dalam evolusi seni rupa Bali selanjutnya (Couteau 1999).

Menurut Sairin (2002), pada dasarnya perubahan budaya bukan peristiwa tunggal, melainkan peristiwa yang memiliki keterkaitan antara satu unsur dengan unsur lain. Perubahan merupakan sebuah proses yang terjadi dalam masyarakat yang sedang mengalami berbagai peristiwa di bidang sosial, ekonomi, politik, dan budaya. Unsur-unsur perubahan tersebut dapat dipengaruhi baik oleh faktor internal maupun eksternal. Setiap perubahan yang berlangsung direspons secara beragam oleh masyarakat yang mengalaminya baik dengan sikap statis, adaptif, reaktif, maupun kreatif tergantung pada kondisi lingkungan yang memengaruhinya. 
Dalam tulisan ini, perubahan yang terjadi dalam seni rupa di Bali dipengaruhi faktor eksternal berupa proses penjajahan yang diikuti oleh kedatangan seniman-seniman asing ke Bali. Faktor internal adalah adanya penerimaan dari masyarakat Bali seperti yang dikatakan oleh Sanento Yuliman, bahwa dinamisasi seni lukis di Bali memang tidak dapat dipisahkan dari peran orang-orang asing yang tinggal di desa dan berinteraksi secara langsung dengan seniman di Bali, terutama Rudolf Bonnet dan Walter Spies dan berdirinya Kelompok Pita Maha. Tumbuhnya seni lukis dengan ciri baru tersebut juga tergantung pada kelenturan jiwa pelukis-pelukis di Bali untuk menerima hal-hal baru dan adanya kesiapan untuk berubah. Peran masyarakat Bali sebagai pelaku kesenian bersifat aktif dalam menanggapi pengaruh luar untuk dijadikan sarana pembaruan kesenian masyarakat Bali (Yuliman 2001).

Seni lukis sebagai salah satu bentuk kesenian keberadaannya tidak bisa dilepaskan dari konteks masyarakat yang melingkupinya. Hausser melihat hubungan seni dan masyarakat tidaklah monolitik, masing-masing bisa menjadi objek dan subjek. Hal tersebut menjadi dasar untuk meletakkan seni sebagai produk masyarakat dan masyarakat sebagai produk seni. Seni lukis Bali juga mengambil konsep local genius khas Bali yakni konsep-konsep lokal yang memiliki nilai universal seperti: konsep dualistis atau Rwa Bhineda yang bermakna keseimbangan hidup manusia dalam dimensi dualitas atau percaya terhadap adanya dua kekuatan dahsyat seperti baik dan buruk, siang dan malam, laki-laki dan perempuan, kaja dan kelod, serta sekala dan niskala (Sucitra 2015).

Hauser memandang hasil karya seni tergantung pada proses sosiohistoris. Terdapat beberapa faktor yang memengaruhi karya seni, yaitu alam, kebudayaan, geografi, ras, serta tempat dan waktu. Hauser juga menekankan bahwa karya seni yang dihasilkan oleh seorang seniman sebagai individu ia terkait dengan ketertarikan, pandangan, kesempatan, kekuatan nilai, dan keterlibatannya dalam sebuah kelompok.

Menurut pendapat tersebut, dengan demikian, dalam melihat fenomena kesenian tidak bisa dilepaskan dari konteks sosial-budaya yang melingkupi sebuah fenomena kesenian. Hausser lebih lanjut juga mengungkapkan bahwa faktor sosial dan budaya tidak hanya berpengaruh dalam proses historis sebagai substrata dari ekspresi kesadaran dan kehendak individu, tetapi juga sebagai prinsip-prinsip dari dinamika dan mobilitas individu. Struktur dalam masyarakat yang meliputi kelas, profesi, komunitas, lingkaran sosial, dan lainlain selalu mengalami perubahan. Individu sebagai bagian dari masyarakat bagaimanapun juga bergerak dari satu kategori sosial satu ke kategori sosial yang lain (mengalami mobilitas horizontal dan vertikal) meskipun kondisi eksternal tidak berubah. Ekspresi visual dari individu dalam periode dan situasi yang berbeda akan merefleksikan kondisi sosial budaya di sekelilingnya.

Tulisan ini secara umum akan menggambarkan sejauh mana perubahan dan keberlanjutan seni lukis Bali dari masa sebelum kolonial (adanya Kelompok Seni Pita Maha) dengan masa sesudahnya. Kajian sosiohistoris untuk melihat bagaimana lapis-lapis sejarah telah melahirkan tatanan baru seni rupa dirasa penting karena akan membantu memahami kekuasaan wacana seni rupa modern yang seakanakan pada saat yang bersamaan telah meminggirkan seni tradisi. Tulisan ini masih prematur dan membutuhkan kajian yang lebih mendalam mengenai perubahan-perubahan dari seni rupa pra-kolonial Bali menjadi seni rupa masa kini.

\section{Seni Rupa Bali Sebelum Penjajahan}

Sebelum membahas proses perubahan yang telah terjadi dalam seni rupa di Bali yang tampak setelah kedatangan para seniman dari luar negeri akan dipaparkan mengenai jejak-jejak seni rupa yang sudah ada terlebih dahulu di Bali. Hal ini untuk melihat proses perubahan tersebut terjadi. Sebelum penjajahan, seni rupa di Bali digunakan untuk kepentingan keagamaan yaitu agama Hindu dan untuk kepentingan menghias pura atau rumahrumah golongan masyarakat dari kasta atas di Bali. Para seniman tersebut bekerja untuk mengabdi atau ngayah. Karya-karya seni rupa tersebut diwujudkan ke dalam bentuk tokoh dewa, pahlawan-pahlawan, wiracarita, dan figur-figur legendaris yang tampil berbusana dengan hiasan rumit, serta menggunakan 
gelung-gelung terstilisasi dan penutup-penutup kepala tokoh-tokoh wayang digambarkan dalam bentuk profil, tetapi dengan dua mata tampak di depan, lengan-lengan kurus bersiku-siku, dan dihiasi dengan pola-pola pepohonan, gununggunung, kolam-kolam, dan awan-awan (Holt 2000).

Pada masa prakolonial, seni lukis merupakan bagian dari keperluan ritual keagamaan sehingga perwujudannya sangat dipengaruhi oleh nilai-nilai relijius (Hindu) seperti penggunaan warna merah, hitam, putih, dan kuning keemasan yang dominan. Warna-warna tersebut mencerminkan simbol dari kepercayaan yang hidup di masyarakat Bali. Warna merah melambangkan Dewa Brahma, warna putih merupakan lambang dari Dewa Wisnu, warna hitam adalah lambang Dewa Siwa. Selain penggunaan warna juga hadirnya motif poleng (kotak persegi empat dengan warna hitam-putih) yang melambangkan konsep mandala yang melihat hubungan dan sifat-sifat manusia dengan alam dan penciptanya berkaitan dengan empat arah mata angin.

Seni lukis tradisional Bali dapat dilihat dalam bentuk-bentuk karya seni antara lain: (1) prasi atau ilustrasi dalam manuskrip di atas daun tal atau daun lontar (palmyra); (2) parba atau lukisan di atas kain-kain persegi panjang atau panel-panel kayu terletak di bagian belakang tempat tidur yang diletakkan di rumah tradisional Bali (bale), berfungsi sebagai backdrop. Panel-panel ini dihiasi dengan lukisan bertemakan mitologi atau kalender (palalintangan); (3) tabing atau lukisan di atas kain atau kayu berisi cerita-cerita tentang kehidupan setelah kematian digunakan untuk menghiasi perlengkapan untuk kremasi; (4) palelintangan atau kalender persegi bergambar di atas kain yang berisi gambar mengenai hari-hari baik dengan tema-tema kehidupan sehari-hari seperti pencari ikan, orang yang sedang memanen padi, dan lain-lain; (5) langse atau lukisan pada kain yang digunakan sebagai tirai untuk penutup atau hiasan pura; (6) ider-ider atau lukisan di atas kain panjang dengan lebar 1 sampai 1,5 kaki, yang di atasnya terdapat lukisan dengan cerita wayang beber yang dibagi dalam beberapa adegan masing-masing adegan dipisahkan dengan motif lidah api, motif awan, dan motif gunung.
Gulungan kain panjang ini digantung di sepanjang lis-lis atap bangunan pura atau bale pada saat perayaan-perayaan ritual; (7) ulon atau kain putih yang dilukis merepresentasikan Dewa Indra atau Tintya untuk menyelimuti orang yang meninggal; (8) kober disebut juga lelontek atau umbulumbul bendera yang merepresentasikan mitologi tertentu; (9) lamak atau panil-panil persegi panjang tempat-tempat sesaji terbuat dari daun kelapa muda dihias dengan motif pohon yang distilisasi (kayon) dan figur wanita yang distilisasi disebut cili dan dipercaya sebagai simbol kesuburan dan keberuntungan; (10) rerajahan (tumbal) gambar atau lukisan yang dianggap mempunyai kekuatan magis. Dilukis di atas kotak atau kursi (Couteau 2003).

Lukisan-lukisan tradisional tersebut mempunyai ciri-ciri umum, yaitu bersumber dari karakter gaya wayang klasik dengan tema cerita dari Mahabharata, Ramayana, cerita-cerita Panji, juga mitologi-mitologi Bali. Tema-tema yang disenangi antara lain: Arjuna Wiwaha yang bercerita tentang keteguhan serta kemauan keras dari Arjuna untuk bertapa demi memenangkan bantuan para dewa dalam mengalahkan musuh-musuhnya, Bima Swarga, bercerita tentang kemarahan dan pemberontakan Bima terhadap dewa-dewa karena keputusan para dewa untuk menghukum mati Pandu, ayah Bima, sedangkan Suthasoma bercerita tentang kepatuhan Suthasoma mengorbankan dirinya untuk dimakan harimau yang telah mengacau desa. Nilai-nilai mengenai keteguhan hati serta kemauan keras dalam menjalani tapa untuk mencapai suatu tujuan, kesetiaan tanpa pamrih kepada orang tua, serta kesetiaan dan pengorbanan untuk kebaikan masyarakat adalah nilai-nilai yang sangat dihargai orang Bali. Karya-karya tersebut dalam bentuk gulungan yang sewaktu-waktu bisa dilihat dan menjadi semacam media pendidikan bagi masyarakat luas sekaligus menjadi salah satu sumber acuan etika dan estetika bersama.

Teknik-teknik melukis yang digunakan antara lain: nyawi (menegaskan sketsa dengan tinta Cina), ngabur ( mengesankan gelap terang), nguap (memberi warna transparan secara merata), nyenter (memberi pencahayaan dengan warna putih atau kuning), ngewarna (mewarnai), manyunan (mem- 
buat detail dan ornamen) serta menyelesaikannya dengan memberi detail dan beberapa warna tambahan, ngucek atau membuat lukisan lebih berdimensi dan lebih cerah (Picard 2000).

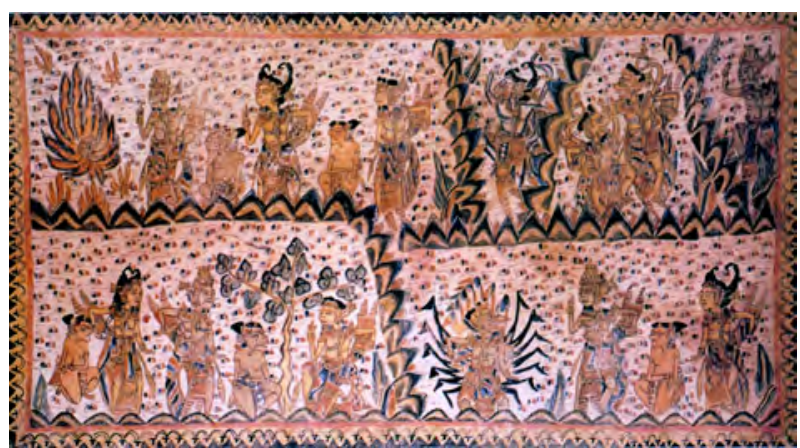

Gambar 1. Lukisan tradisional Bali pada manuskrip di atas daun tal/lontar/palmyra. (Foto reproduksi Buku Indonesia Heritage: Visual Art, hlm. 110)

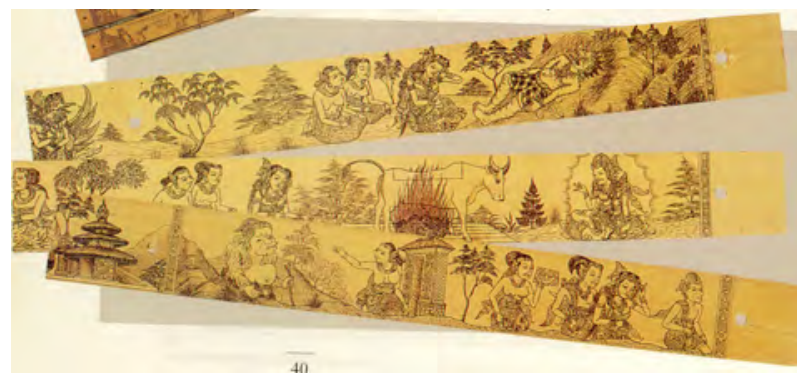

Gambar 2. Figur wayang pada lukisan klasik Kamasan abad ke-18. (Foto reproduksi Buku Indonesia Heritage: Visual Art, hlm. 110)

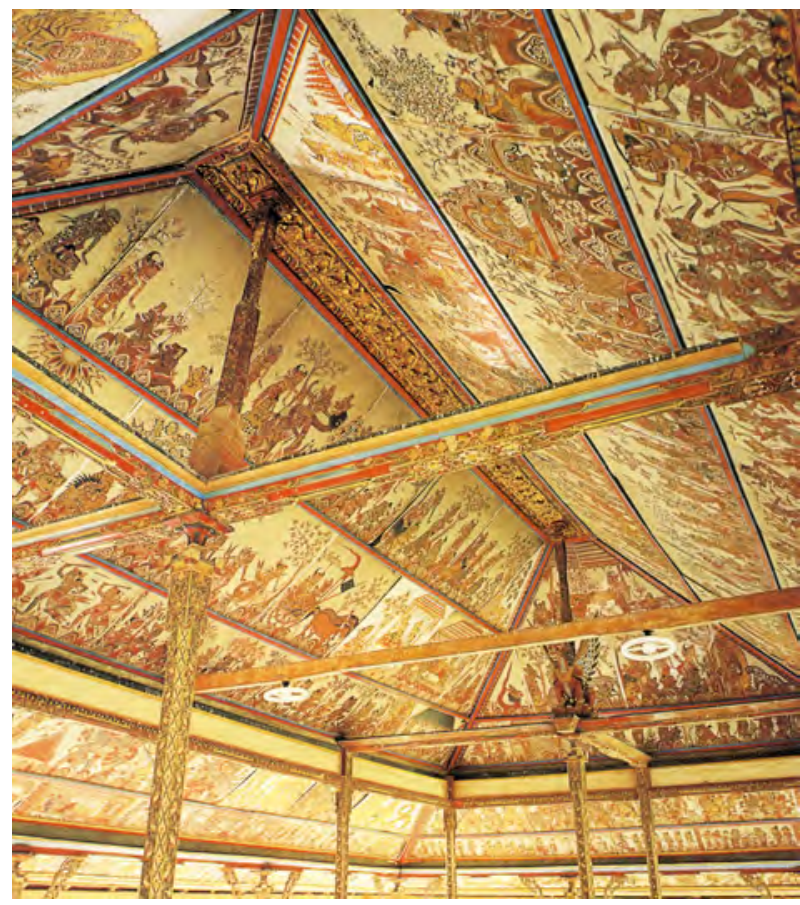

Gambar 3. Contoh lukisan tradisional Bali pada atap Bale Kambang bagian dari bangunan gedung Pengadilan Kerta Gosa yang dilukisi dengan mengambil tema Bhima Swarga. (Foto reproduksi Buku Indonesia Heritage: Visual Art, hlm. 110)
Material yang dipakai dalam lukisan tradisonal Bali diperoleh dari cat-cat buatan lokal. Warnawarna tersebut di antaranya adalah kuning dan cokelat, daun taum untuk menghasilkan warna hijau atau biru, gincu (yang diperoleh dari serbuk Cina warna merah vermillion) untuk warna merah, tulang babi untuk warna abu-abu dan warna putih, sejenis batu belerang untuk menghasilkan warna kuning dan cokelat, pere untuk menghasilkan warna cokelat, pena bambu, kain nusa, serat daun tal (palmyra) dan ancur yang digunakan sebagai perekat warna (Couteau 1999).

\section{Kelompok Pita Maha: Menuju Seni Lukis Modern di Bali}

Gelombang 'modernis' Bali adalah produk transfer of knowledge (peralihan pengetahuan). Selain teknik dan pendekatan stilistik tertentu
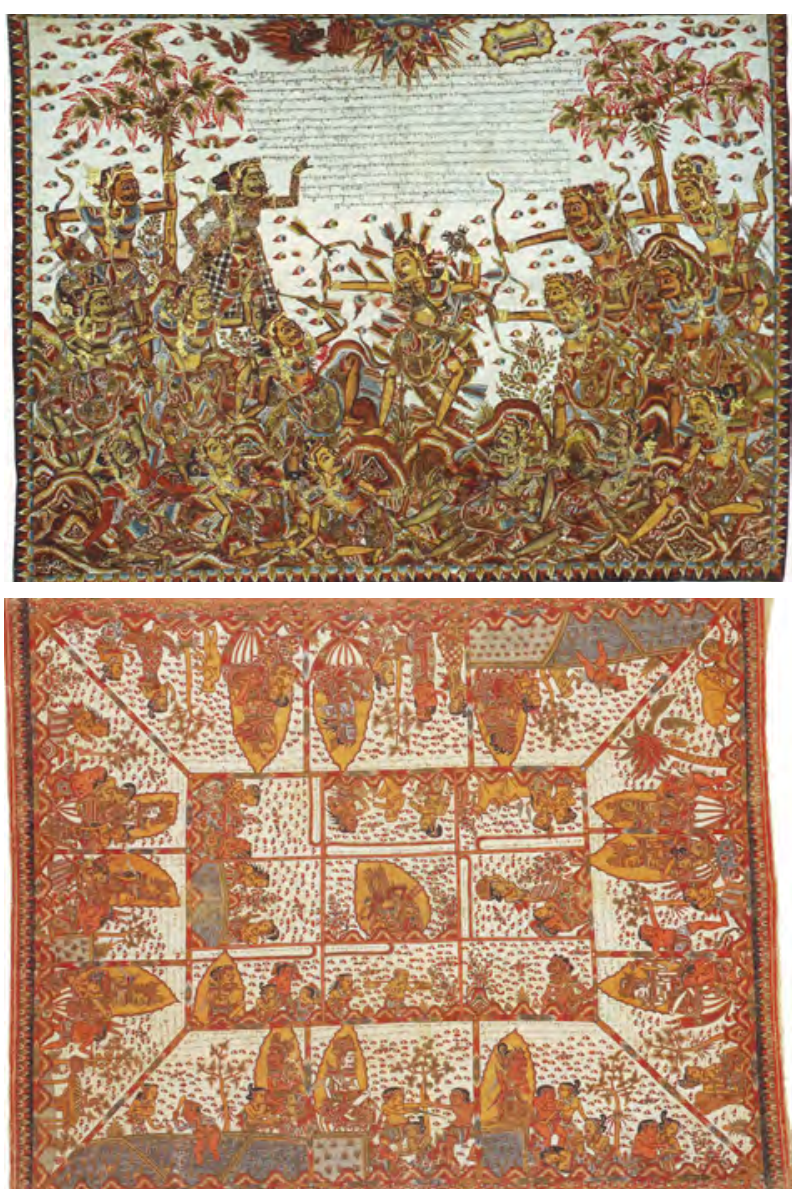

Gambar 4. Contoh lukisan tradisional Bali: Pan Seken, Baratayudha: Kematian Abimanyu, pigmen dan pewarna alam di atas kain, 1930 (gbr. atas) dan Nyoman Dogol, Pelelintangan, 1930 (gbr. bawah). (Foto reproduksi Buku Crossing Boundaries, Bali: A Window to Twentieth Century Indonesia Art, 2002) 
dalam karya seni, proses peralihan pengetahuan tersebut juga mengubah cara pandang seniman Bali dalam berkarya dan memperlakukan karya seni (Couteau 2003).

Agus Burhan menyebutkan bahwa bentukbentuk estetis dalam perkembangan seni rupa modern Indonesia merupakan adaptasi dari berbagai gaya dan aliran modern yang berasal dari Barat. Dalam adaptasi-adaptasi tersebut tercermin metamorfosis dan sintesis paradigma serta bentuk estetis seni rupa Barat yang telah disesuaikan dengan konteks sosiokultural Indonesia (Burhan 2003).

Artinya konsep seni rupa modern di sini adalah seni rupa yang seperti di Barat, tetapi melalui proses kesejarahan yang berbeda (yaitu untuk mempertanyakan dan mengubah secara sistematis seni rupa sebelumnya). Nilai-nilai seni modern yang terdapat dalam karya-karya yang dihasilkan oleh seniman anggota Kelompok Pita Maha bisa dilacak dalam karya, praktik, dan pola berkesenian.

Evolusi seni rupa Bali dimulai di Buleleng (Bali Utara) meski menyangkut segi yang sekunder seperti mulai diperkenalkan dengan bahanbahan modern seperti kertas, gambar dibuat satu adegan saja dan bukan narasi lengkap seperti pada lukisan wayang klasik. Beberapa gambar sudah memperlihatkan awal strukturisasi ruang, dan sudah mulai mengarah ke unsur tematika baru. Hal-hal tersebut sudah memperlihatkan meresapnya unsur-unsur baru pada tatanan seni rupa Bali (Couteau 1999).

Pada awal abad ke-20 seni lukis Ubud tumbuh dengan gerak penciptaan yang mirip gaya seni lukis Kamasan dengan tema-tema wayang. Para tokohnya saat itu adalah I Made Geria, I Wayan Togog, Ida Bagus Kembong, Tjokorda Oka Gambir, I Gusti Nyoman Lempad, dan lain-lain. Kedatangan dua seniman asing Walter Spies disusul Rudolf Bonnet turut menyumbangkan bentuk, tema, dan gaya seni lukis Ubud. Kedatangan dua seniman asing tersebut atas undangan dari pemimpin Puri Ubud Tjokorda Gede Raka Sukawati (Dermawan T. 2006).

Kelompok Pita Maha didirikan 29 Januari 1936 oleh Walter Spies dan Rudolf Bonnet. Pita
Maha berasal dari bahasa Kawi yang mempunyai arti "grand ancestor(s)" atau nenek moyang. Sejak awal berdirinya tercatat memiliki anggota lebih dari 150 orang. Rudolf Bonnet mengatakan bahwa Pita Maha merupakan sebuah serikat pekerja seni di Bali. Tujuan pertamanya adalah untuk merangsang seni dan kedua untuk memberikan minat dalam kemudahan bahan kepada para anggotanya. Karyakarya pekerja seni diseleksi oleh para ahli seni dan dapat diperoleh di Museum Bali di Denpasar. Seleksi ini akan menguntungkan pembeli. Untuk seleksi ini Pita Maha hanya mengambil sedikit untuk menutup biaya (Picard 2000).

Spies dan Bonnet hidup di tengah masyarakat Ubud di bawah naungan puri. Melalui dukungan dari Tjokorda Agung Sukawati, Bonnet dan Spies yang dianggap sebagai "guru" oleh seniman tradisional Bali, lebih mudah masuk dan diterima oleh seniman setempat. Karya Spies dan Bonnet kemudian dijadikan panutan sehingga memunculkan karya-karya turunan Spies dan Bonnet yang sampai saat ini banyak terlihat di daerah Ubud, Batuan, dan Sanur. Menciptakan gaya yang disebut Gaya Ubud, Gaya Batuan, dan Gaya Sanur (Couteau 1999).

\section{Gaya Ubud}

Pengaruh Spies dan Bonnet tampak dalam pengolahan komposisi yang lebih dinamis,

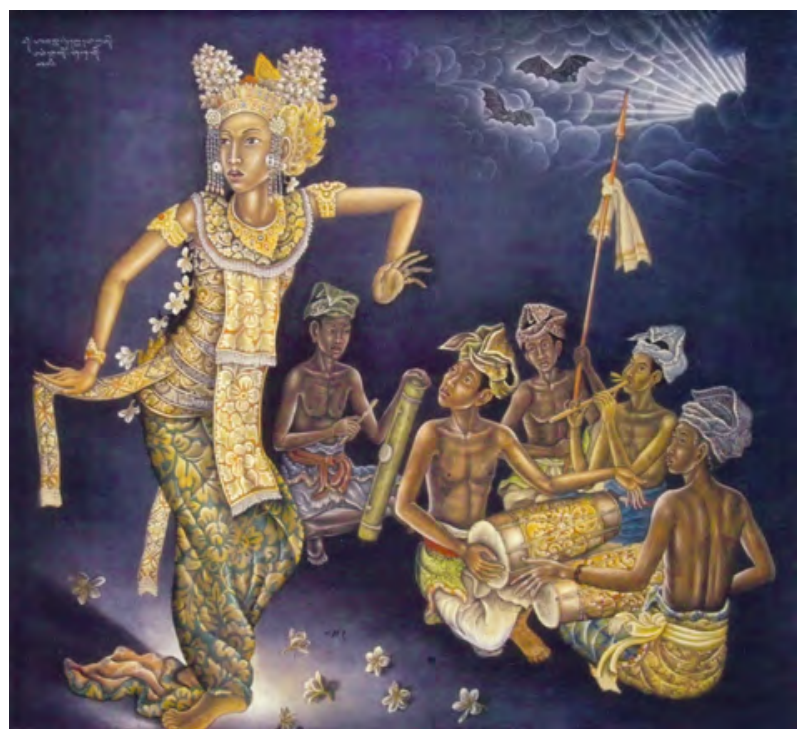

Gambar 5. Anak Agung Gde Sobrat, "Tari Arja”, akrilik, tempera, di atas kanvas. (Foto reproduksi Buku Perjalanan Seni Lukis Indonesia: Koleksi Bentara Budaya, hIm. 228) 
penggarapan perspektif, dan pengayaan warna. Dalam hal ini juga mulai diperkenalkan dengan bahan-bahan melukis yang didatangkan dari Belanda seperti tempera, cat air, dan cat minyak. Pengaruh tersebut terlihat dari mulai dikenalnya teknik chiarrascuro (gradasi gelap terang) khas Spies dan anatomi khas Bonnet Seniman yang mengakrabi Gaya Ubud antara lain adalah I Gusti Nyoman Lempad, Anak Agung Gde Sobrat, Ida Bagus Made Poleng, I Gusti Ketut Kobot, I Dewa Putu Bedil, Ida Bagus Nadera, Ida Bagus Rai, dan lain-lain (Couteau 1999).

\section{Gaya Batuan}

Lukisan-lukisan Gaya Batuan berciri khas suasana malam hari yang menakutkan ketika hantuhantu dalam bentuk yang aneh, monster-monster binatang ganjil, penyihir-penyihir wanita, dan mayat-mayat penghisap darah mendekati orang. Tidak nampak jejak dari gaya wayang. Objekobjek, figur-figur manusia digambar frontal dan dalam bentuk profil. Upaya untuk memunculkan

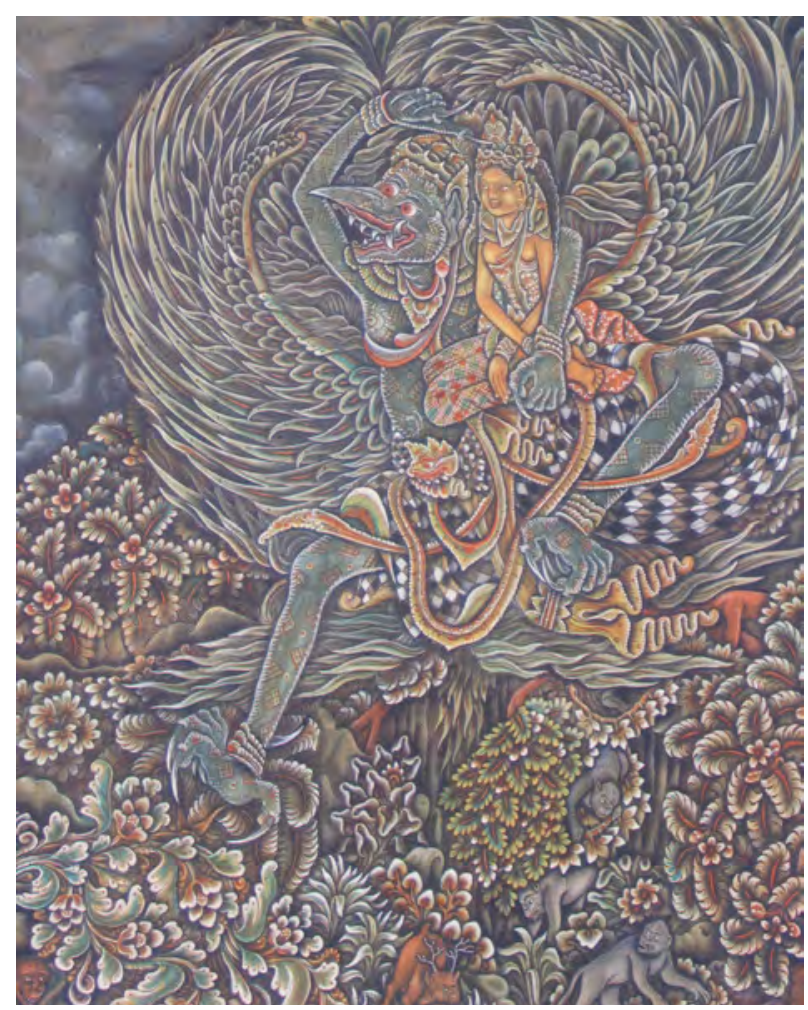

Gambar 6. Contoh lukisan Gaya Batuan Karya I Gusti Made Togog, "Jatayu Membawa Shinta", memiliki kekhasan dalam pemberian warna dan pelukisan tokohnya yang merupakan makhluk mitologi menyeramkan. (Foto reproduksi Buku Perjalanan Seni Lukis Indonesia: Koleksi Bentara Budaya, hlm. 228) kedalaman dalam lukisan dilakukan lewat pelukisan perspektif yang didistorsi secara naif. Akan tetapi, gunung-gunung, pohon-pohon, dedaunannya, dan bunga-bunga yang besar tetap distilisasi secara dekoratif seperti pada lukisan-lukisan tradisional Bali (Holt 2000).

Selain itu, lukisan Gaya Batuan juga dicirikan dengan makhluk-makhluk magis yang menakutkan, suatu ekspresi personal dari dunia mistis dan kepercayaan Bali. Seniman yang terkenal antara lain adalah I Ngendon, seniman berpendidikan modern, yang karyanya dalam beberapa tahun berkembang dari gaya wayang ke pemandangan dan bahkan potret. Seniman penting lainnya adalah Ida Bagus Togog, Ida Bagus Wija, I Tomblos, I Patera (Couteau 1999).

\section{Gaya Sanur}

Di Sanur muncul gaya lukisan yang terinspirasi oleh laut dan kehidupan sehari-hari juga gaya naif dengan teknik lapis tinta Cina yang canggih. Sebanyak seniman yang menggambarkan kehidupan laut, makhluk-makhluk laut, kura-kura, kepiting, dan adegan-adegan mandi. Seniman yang menekuni Gaya Sanur antara lain adalah Ida Bagus Nyoman Rai, I Ketut Regig (Couteau 1999).

Setelah penjajahan dan munculnya Pita Maha, pola-pola berkesenian di Bali mengalami perubahan. Terutama dalam penggunaan alat dan bahan melukis mulai menggunakan kanvas dan

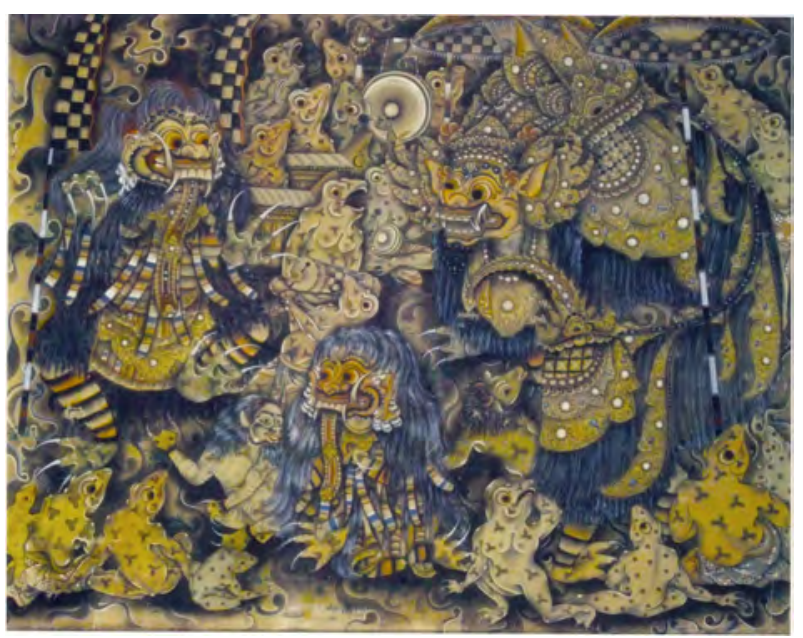

Gambar 7. Contoh lukisan gaya Sanur karya I Ketut Regig, "Barong Kodok", 1971. Dalam lukisannya terdapat binatang-benatang seperti kodok dan belalang. (Foto reproduksi Buku Perjalanan Seni Lukis Indonesia: Koleksi Bentara Budaya, hlm. 216) 
cat-cat yang berbahan dasar kimia, teknik-teknik baru seperti sfumato, chiarrascuro. Selain itu, mulai bergesernya orientasi dalam menciptakan karya seni yang juga digunakan untuk memenuhi permintaan pasar selain untuk kepentingan religi. Seni prakolonial, meskipun demikian tetap tumbuh dengan subur dan kuat di Bali, dan berjalan berdampingan dengan seni rupa modern hingga saat ini.

\section{Simpulan}

Melalui kehadiran Walter Spies, Rudolf Bonnet, Tjokorda Raka Sukawati, dan Pita Maha yang bisa disebut sebagai agent of change, menandai terjadinya sejumlah perubahan penting dalam tatanan seni rupa Bali. Perubahan tersebut meliputi: (a) aspek teknis melukis, pengenalan media kertas, tripleks, kanvas, pengayaan warna, dan penggunaan cat buatan pabrik. Mulai menggunakan perspektif dan gradasi warna sehingga memunculkan kesan dimensi ruang dalam lukisan, mulai menampilkan cirri-ciri anatomis (lukisan tidak lagi flat seperti lukisan wayang sebelumnya); (b) aspek tematis, terjadi komodifikasi pada tema lukisan, yaitu sekularisasi dari representasi karya seni rupa yang digunakan untuk kepentingan religius dan bersumber dari epos klasik India seperti Mahabharata dan Ramayana menjadi lebih beragam untuk memenuhi permintaan pasar sebagai benda suvenir; (c) terjadi pola perubahan dalam praktik kesenian, yang semula ditujukan semata-mata untuk kepentingan agama dan kerajaan beralih untuk kepentingan ekonomi; (d) karya seni bukan lagi sebagai karya yang anonim, kolektif, dan komunal, muncul penghargaan terhadap individu; (e) pengayom/pelindung/patronase bergeser dari raja, bangsawan, dan para elit birokrasi, menjadi masyarakat pedesaan, para birokrat kota, dan bisnis pariwisata.

Meskipun terjadi perubahan, dalam seni lukis setelah Pita Maha masih bisa dilacak ciri-ciri kesenian Bali prakolonial, yaitu ruang yang diisi penuh dengan objek-objek lukisan yang berasal dari kisah-kisah Mahabharata dan Ramayana terutama kisah Suthasoma, Arjuna Wiwaha, Bima Swarga, detail pada warna dan objek, dan ikon-ikon dari khazanah tradisi yang masih terpatron secara ketat. Pelukis-pelukis dari Bali sampai saat ini masih melakukan pola berkesenian untuk kepentingan religius sekaligus juga untuk memenuhi permintaan pasar. Seni rupa modern Bali setelah Pita Maha sangat terkait dengan nilainilai lokal yang kemudian menjadi sumber inspirasi dalam penciptaan karya seni lukis. Artinya, seni rupa modern Bali mempunyai ciri yang khas dan berbeda dengan seni rupa modern dari Barat. Melalui studi mengenai sejarah fenomena kesenian kelompok seni Pita Maha terlihat gerak perubahan yang terjadi dalam seni rupa di Bali sehingga bisa melakukan evaluasi, kritik, dan memperoleh pengetahuan untuk melihat pola-pola perubahan dan dampaknya terhadap seni rupa saat ini.

\section{Ucapan Terima Kasih}

Atas terselesaikannya tulisan ini, penulis mengucapkan terima kasih kepada: (1) Bentara Budaya Yogyakarta, (2) Program Pascasarjana ISI Yogyakarta, dan (3) Prof. Dr. M. Agus Burhan.

\section{Kepustakaan}

Burhan, M.A., 2003. "Seni Rupa Modern Indonesia: Tinjauan Sosiohistoris." In A. Wicaksono (ed.) Politik dan Gender: AspekAspek Seni Visual Indonesia. Yogyakarta: Yayasan Seni Cemeti.

Couteau, J., 1999. Museum Puri Lukisan. Bali: Yayasan Ratna Wartha.

Couteau, J., 2003. "Wacana Seni Rupa Bali Modern.” In A. Wicaksono (ed). Aspek-aspek Seni Visual Indonesia: Paradigma dan Pasar. Yogyakarta: Yayasan Seni Cemeti.

Dermawan T., A., 2006. Bali Bravo. Jakarta: Panitia Bali Bangkit.

Holt, C., 2000. Melacak Jejak Perkembangan Seni di Indonesia (Terj. R. M. Soedharsono). Bandung: MSPI.

Picard, M., 2000. "Pita Maha." In H. Soemantri (ed). Indonesian Heritage: Visual Art. Singapore: Archipelago Press.

Sairin, S., 2002. Perubahan Sosial Masyarakat Indonesia Perspektif Antropologi. Yogyakarta: Pustaka Pelajar. 
Sucitra, I.G.A., 2015. “Transformasi Sinkretisma Indonesia dan Karya Seni Islam”. Journal of Urban Society's Arts, Volume 2 (No. 2-Oktober), pp.89-103.

Vickers, A., 2000. "Innovation in Tradition." In
H. Soemantri (ed). Indonesian Heritage: Visual Art. Singapore: Archipelago Press.

Yuliman, S., 2001. "Dinamika Bali di Batuan." In A. Hasan (ed). Dua Seni Rupa. Jakarta: Yayasan Utan Kayu. 